\title{
Association of the lactococcin A immunity factor with the cell membrane: purification and characterization of the immunity factor
}

\author{
Jon Nissen-Meyer, ${ }^{1,2}$ Leiv Sigve Håvarstein, ${ }^{1}$ Helge Holo,,${ }^{1}$ Knut Sletten ${ }^{2}$ and \\ INGOLF F. NES ${ }^{1 *}$ \\ ${ }^{1}$ Laboratory of Microbial Gene Technology, NFR, Agricultural University of Norway, PO Box 5051, \\ $N-1432$ As, Norway \\ ${ }^{2}$ Department of Biochemistry, University of Oslo, Norway
}

(Received 22 December 1992; revised 19 February 1993; accepted 15 March 1993)

\begin{abstract}
The physicochemical characteristics of the lactococcin A immunity protein, as deduced from its gene sequence, were used to devise a procedure for its purification. The protein was purified from cell extracts by cation-exchange and reverse-phase chromatography. As judged from the amino acid composition and amino acid sequencing, the immunity protein is not post-translationally processed by cleavage at its $\mathrm{N}$ - or $\mathrm{C}$-terminus. Consequently, the absorption coefficient at $280 \mathrm{~nm}$, the isoelectric point, and the molecular mass of the immunity protein may be calculated to be, respectively, $8.2 \times 10^{3} \mathrm{M}^{-1} \mathrm{~cm}^{-1}, 10.2$ and $11163 \mathrm{Da}$ from the amino acid sequence predicted from the nucleotide sequence. The immunity protein is a major cell protein component - one cell may contain (to an order of magnitude) $10^{5}$ molecules - and it is in part associated with the cell membrane, as judged by immunoblot analysis of membrane vesicle-associated proteins. Exposing lactococcin-A-sensitive cells to an excess of the immunity protein did not affect the lactococcin-A-induced killing of the cells, indicating that the immunity protein does not protect cells by simply binding to lactococcin A, nor to externally exposed domains on the cell surface. Exposing immune-positive cells to antiserum against the immune protein did not sensitize the cells to lactococcin A, suggesting that the immunity protein in fact does not act extracellularly.
\end{abstract}

\section{Introduction}

Bacteriocins are bacteria-produced polypeptides which have a bactericidal and/or bacteriostatic effect, usually directed towards bacteria which are closely related to the bacteriocin-producing species (Tagg et al., 1976). In order to protect themselves against the toxic effect of their own bacteriocin, bacteriocin-producing cells generally also produce an immunity protein (Konisky, 1982). This protein renders a cell resistant to its own bacteriocin, but not necessarily to other unrelated bacteriocins.

There has been considerable interest in lactic acid bacteria (LAB)-produced bacteriocins, due to their potential use as antimicrobial agents. Nisin was for a long time the only thoroughly studied LAB bacteriocin (Buchman et al., 1988; Dodd et al., 1990; Gross \& Morell, 1971; Hurst 1981; Kaletta \& Entian, 1989; Sahl et al., 1987). Recently, however, several new LAB bacteriocins have been identified, purified and

*Author for correspondence. Tel. 4764949471 ; fax 4764941465.

Abbreviation: LAB, lactic acid bacteria. characterized (Hastings et al., 1991; Henderson et al., 1992; Holo et al., 1991; Mørtvedt et al., 1991; Muriana \& Klaenhammer, 1991 $a, b$; Nieto Lozano et al., 1992; Nissen-Meyer et al., 1992; Piard et al., 1992; Stoffels et al., 1992; Tichaczek et al., 1992; van Belkum et al., 1991a). Lactococcin A, produced by Lactococcus lactis subsp. cremoris, is perhaps the most studied among these new LAB bacteriocins. It is an unmodified polypeptide, 54 amino acid residues long, which does not share any apparent amino acid sequence homology with other isolated bacteriocins (Holo et al., 1991). Lactococcin A appears to induce cell death by permeabilizing the membrane of susceptible cells (van Belkum et al., 1991 b). Evidence for the existence of a lactococcin A immunity protein is based on the identification of a gene whose presence in a functional form in a cell renders the cell resistant to lactococcin A (Holo et al., 1991; van Belkum et al., 1991a). Upon cloning and sequencing the lactococcin A gene, the gene encoding the lactococcin A immunity protein was identified and sequenced (Holo et al., 1991; van Belkum et al., 1991 a). The presence of the immunity gene in a functional form is sufficient to render a cell resistant to lactococcin A. Judging from the 
nucleotide sequence of this gene, it should encode a cationic protein with a molecular mass of approximately $11000 \mathrm{Da}$.

It is not known how immunity proteins render cells resistant to the toxic effect of LAB bacteriocins. This lack of knowledge may be partly due to inability to isolate and thereby thoroughly characterize LAB immunity proteins. One major hindrance to purifying an immunity protein is the lack of a functional assay. However, some of the physicochemical characteristics of an immunity protein may be deduced from its gene sequence and these characteristics may then be used to devise a procedure for purification of the protein. In this study we used this strategy to develop a simple three-step procedure for the purification of the lactococcin A immunity protein to homogeneity, and we show that a fraction of the protein is associated with the cell membrane. It is to our knowledge the first purification of a LAB bacteriocin immunity protein. The procedure used should be applicable to the purification of other LAB bacteriocin immunity proteins whose genes have been identified and sequenced.

\section{Methods}

Bacterial strains and media. The Lactococcus lactis subsp. cremoris strains LMG 2130 and LMG 2131, and the subsp. lactis strains IL 1403 and IL 1403(pON7) used in this study have been described previously (Holo et al., 1991). Strain LMG 2130 is the lactococcin A producer from which lactococcin A was originally identified and isolated (Holo et al., 1991). In addition to the lactococcin A gene, this strain contains the gene encoding the lactococcin A immunity protein. Strain LMG 2131 was derived from LMG 2130 after exposing the latter to plasmid curing, resulting in the loss of both the lactococcin A gene and the immunity gene in LMG 2131 (Holo et al., 1991). Strain IL 1403 is a lactococcin-A-sensitive strain which lacks the immunity gene, and this strain has been used as indicator strain in the bacteriocin assay when measuring lactococcin A activity (Holo et al., 1991). Strain IL 1403(pON7) was derived by transforming IL 1403 with the genes encoding lactococcin A and its immunity protein (Holo et al., 1991). IL 1403(pON7) has as a consequence become resistant to lactococcin A, and it produces a small amount of the bacteriocin (Holo et al., 1991). All strains were grown and maintained in M17 broth as described earlier (Holo et al., 1991).

Preparation of bacterial extracts. Bacterial cultures (2 litres) were grown to the late exponential/early stationary phase. The cells were collected by centrifugation at $4000 \mathrm{~g}$ for $15 \mathrm{~min}$ at $4{ }^{\circ} \mathrm{C}$, and washed three times in 20 mM-phosphate buffer, pH 7 (buffer A). The cells were then resuspended in $20 \mathrm{ml}$ buffer $A$ and incubated for $40 \mathrm{~min}$ at $37^{\circ} \mathrm{C}$ in the presence of $2 \mathrm{mg}$ lysozyme $\mathrm{ml}^{-1}$. Triton $\mathrm{X}-100$ was then added to a final concentration of $1 \%(\mathrm{v} / \mathrm{v})$ and the preparation was incubated for $40 \mathrm{~min}$ at $4{ }^{\circ} \mathrm{C}$, after which the preparation was centrifuged at $15000 \mathrm{~g}$ for $20 \mathrm{~min}$. The resulting supernatant (bacterial extract, fraction I) was used for purifying the immunity protein when prepared from strain LMG 2130 or IL 1403(pON7), both of which contain the immunity gene.

Purification of the immunity protein. All the purification steps were performed at room temperature; the chromatographic equipment was obtained from Pharmacia-LKB Biotechnology. Bacterial extract (fraction I; $20 \mathrm{ml}$ ) was applied at a flow rate of $1-2 \mathrm{ml} \mathrm{min}^{-1}$ to a $3 \mathrm{ml}$ S-Sepharose Fast Flow cation-exchange column equilibrated with buffer A. After subsequently washing the column with $15 \mathrm{ml}$ buffer A, the immunity protein was eluted from the column with $7 \mathrm{ml} 0.5 \mathrm{M}-\mathrm{NaCl}$ in buffer A (fraction II). Fraction II was diluted to $50 \mathrm{ml}$ with buffer A, after which the fraction was applied at a flow rate of about $1.5 \mathrm{ml} \mathrm{min}-1$ to a Mono S HR 5/5 cation-exchange column equilibrated with buffer A. The proteins which bound to the column were eluted with a linear gradient of $\mathrm{NaCl}$ in buffer $\mathrm{A}$. The immunity protein eluted at a $\mathrm{NaCl}$ concentration between 320 and $380 \mathrm{~mm}$ (fraction III). Fraction III (about $4 \mathrm{ml}$ ) was applied to a $\mathrm{C}_{2} / \mathrm{C}_{18}$ reverse-phase column, PepRPC HR 5/5, equilibrated with $\mathrm{H}_{2} \mathrm{O}$ containing $0 \cdot 1 \%$ trifluoroacetic acid (TFA). The immunity protein was eluted with a linear gradient of 35-55\% 2-propanol containing 0.1\% TFA (fraction IV).

SDS-PAGE of the immunity protein. SDS-PAGE was carried out using PhastGel high-density gels, PhastGel SDS buffer strips, and the PhastSystem (Pharmacia-LKB Biotechnology) according to the manufacturer's recommendations. The molecular mass standards (Pharmacia-LKB) consisted of five peptides with molecular masses between 2500 and $17000 \mathrm{Da}$.

Isolation of membrane vesicles and assay for lactate dehydrogenase. The procedure for preparing membrane vesicles was-with some modifications - similar to that described by Houng et al. (1986). Cells from $200 \mathrm{ml}$ cultures in the late exponential or early stationary phase of growth were pelleted, washed, and resuspended in $4 \mathrm{ml} 50 \mathrm{~mm}$ phosphate buffer, $\mathrm{pH} 7$, containing $7 \mathrm{mM}-\mathrm{MgCl}_{2}$ (buffer B). This preparation was incubated for $1 \mathrm{~h}$ at $37^{\circ} \mathrm{C}$ in the presence of $2 \mathrm{mg}$ lysozyme $\mathrm{ml}^{-1}$. The lysozyme-treated cells were then lysed by a single passage through a French pressure cell at 15000 p.s.i. (103 MPa). The lysed-cell suspension was centrifuged twice for $15 \mathrm{~min}$ at $8000 \mathrm{~g}$. Membrane vesicles in the resulting supernatant fraction were then pelleted by layering $3 \mathrm{ml}$ of the supernatant on an $8 \mathrm{ml}$ sucrose cushion $[10 \%(\mathrm{w} / \mathrm{v})$ sucrose in buffer $\mathrm{B}]$ and centrifuging for $1.5 \mathrm{~h}$ at about $100000 \mathrm{~g}$ using a swinging-bucket rotor. The pellet containing membrane vesicles was resuspended in $3 \mathrm{ml}$ buffer $\mathrm{A}$ and frozen at $-20^{\circ} \mathrm{C}$ (membrane fraction). The supernatant $(3 \mathrm{ml})$, which contains proteins not associated with membranes, was also collected and frozen (cytosol fraction). The protein concentrations in the membrane and cytosol fractions were, respectively, about 0.7 and $3.5 \mathrm{mg} \mathrm{ml}^{-1}$. Protein concentrations were determined by the method of Bradford (1976), using the Bio-Rad Protein Assay Kit.

Lactate dehydrogenase in the membrane and cytosol fractions was assayed by spectrophotometrically monitoring the conversion of $\mathrm{NAD}^{+}$ to NADH using pyruvate as substrate. The Boehringer Mannheim LD/LDH assay kit was used according to the manufacturer's recommendations, except that fructose 1,6-bisphosphate was included ( $1 \mathrm{~mm}$ final concn) in the reaction mixture, and the reaction was carried out at $20^{\circ} \mathrm{C}$. One unit of lactate dehydrogenase activity was arbitrarily defined as the level of enzyme which in 1 min changed the absorbance at $340 \mathrm{~nm}$ by 0.001 in a $1 \mathrm{ml}$ reaction mixture.

Antiserum against the lactococcin A immunity protein. A rabbit was injected subcutaneously three times at 3 week intervals with about $20 \mu \mathrm{g}$ purified immunity protein. The first injection was given with $50 \%$ (v/v) Freund's complete adjuvant, whereas the second and third injections were given with $50 \%$ Freund's incomplete adjuvant.

Immunoblot analysis of membrane-vesicle-associated proteins. For the immunoblot analysis, SDS-PAGE was performed essentially as described by Laemmli (1970), using $17 \%$ (w/v) gels. After SDS-PAGE, proteins were transferred electrophoretically (60 V overnight) to a nitrocellulose membrane. Non-specific protein binding sites on the nitrocellulose membrane were blocked prior to adding antiserum by incubating the membrane for $30 \mathrm{~min}$ with a $3 \%(\mathrm{w} / \mathrm{v})$ dry milk suspension in phosphate-buffered saline (PBS). The membrane was then incubated for $1 \mathrm{~h}$ in $50 \mathrm{ml}$ PBS/Tween $[0.05 \%(\mathrm{v} / \mathrm{v})]$ containing 
both antiserum (1:1000 dilution) against the immunity protein and crude cell extract prepared from a 0.51 culture of an immunity-negative lactococcal strain. The crude extract was included to further reduce non-specific binding of antibodies to the membrane. For preparation of this crude extract, cells were lysed using a French press, and cell debris removed from the extract by centrifugation at $5000 \mathrm{~g}$ for $10 \mathrm{~min}$. The nitrocellulose membrane blots were incubated for $1 \mathrm{~h}$ with alkalinephosphatase-conjugated goat anti-rabbit antibody $(1: 2500)$ (Bio-Rad) followed by washing and incubation in 5-bromo-4-chloro-3-indolyl phosphate (Bio-Rad).

Amino acid composition and sequencing. The purified immunity protein (fraction IV) was hydrolysed and analysed on an amino acid analyser as described earlier (Nieto Lozano et al., 1992). The amino acid sequence was determined by Edman degradation using an Applied Biosystems $477 \mathrm{~A}$ automatic sequencer with an on-line $120 \mathrm{~A}$ phenylthiohydantoin amino acid analyser (Nieto Lozano et al., 1992).

\section{Results and Discussion}

\section{Purification of the lactococcin A immunity protein}

The lactococcin A immunity gene should encode a cationic protein (isoelectric point estimated to be 10.2 ) with a molecular mass of about $11000 \mathrm{Da}$ (or less if it is cleaved post-translationally). Due to the lack of a functional assay for the immunity protein, we used these characteristics as a starting point for purifying the protein.

Although indirect evidence suggests that the immunity protein might be linked to the cell membrane (van Belkum et al., 1991b), it is not certain where in the cell the immunity protein is localized. Consequently, crude whole cell extracts were prepared rather than extracts from subcellular fractions, in order to increase the chance of obtaining extracts which contain the immunity protein. Extracts (fraction I) prepared from the lactococcal strains LMG 2130, LMG 2131, IL 1403, and IL 1403(pON7) were applied to S-Sepharose cationexchange columns at neutral $\mathrm{pH}$. The cationic proteins in the extracts, which all should bind to this column at neutral $\mathrm{pH}$, were then eluted with $0.5 \mathrm{M}-\mathrm{NaCl}$ (fraction II). Upon SDS-PAGE analysis of fraction II obtained from strains LMG 2130 and LMG 2131, more than 30 distinct protein bands could be discerned for each strain (data not shown). The band patterns obtained for the two strains were nearly identical, with the exception that fraction II from LMG 2130 contained a protein which migrated with an apparent molecular mass of 8000-9000 Da which was not detected in fraction II from LMG 2131. The stained protein was barely visible, but it was stained relatively much more strongly by Coomassie staining than by silver staining. This protein was also found in fraction II from strain 1403(pON7), but not from strain IL 1403 . The fact that the protein was only present in strains [LMG 2130, IL 1403(pON7)] which contained and expressed the immunity gene suggested that this might be the immunity protein. Similar amounts of this putative immunity protein were produced by

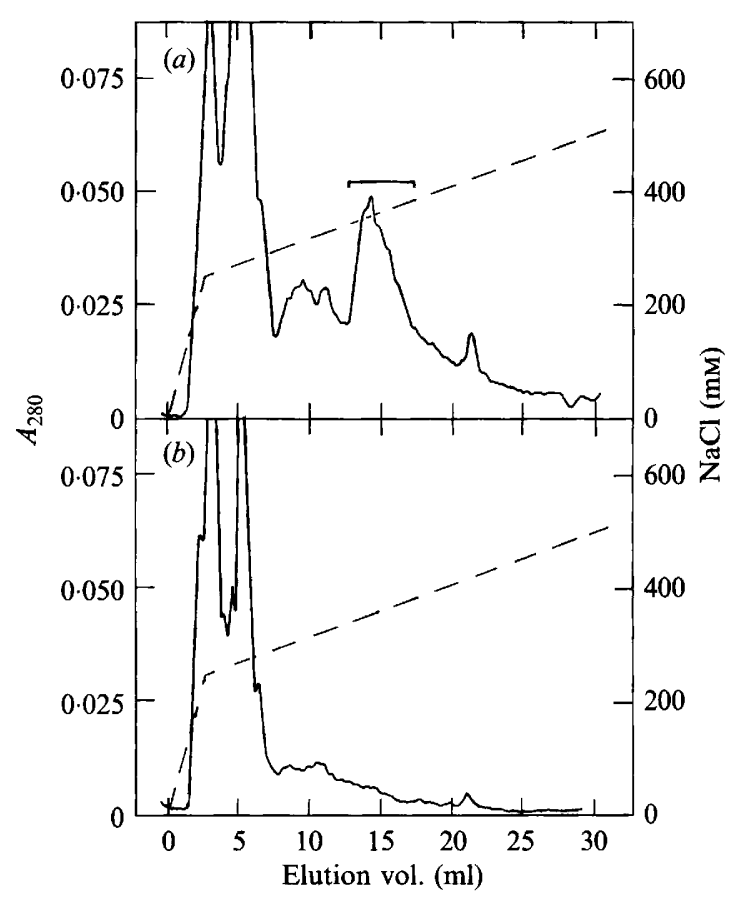

Fig. 1. Chromatography on a Mono S cation-exchange column of fraction II obtained from (a) strain IL 1403(pON7) and (b) strain IL 1403. The flow rate was $1.5 \mathrm{ml} \mathrm{min}{ }^{-1}$ and the fractions applied to the column were from 2 litres culture. The bar indicates the fraction (fraction III) containing the immunity protein.,$- A_{280} ;---, \mathrm{NaCl}$ concn.

strains LMG 2130 and IL 1403(pON7) as judged by the staining intensity of the putative immunity protein band obtained upon SDS-PAGE. However, extracts prepared from LMG 2130 contained greater amounts of contaminating proteins than corresponding extracts from IL 1403(pON7). Extracts prepared from IL 1403(pON7) rather than LMG 2130 were, consequently, used for further purification of the putative immunity protein, using SDS-PAGE analysis as an assay for the protein.

Fraction II from IL 1403(pON7) was applied to a Mono S cation-exchange column and the proteins which bound to the column were eluted with a linear $\mathrm{NaCl}$ gradient (Fig. 1a). Upon SDS-PAGE analysis of the column fractions, the relatively broad $A_{280}$ peak eluting between 320 and $380 \mathrm{~mm}-\mathrm{NaCl}$ (Fig. $1 a$ ) was found to be due to the putative immunity protein (fraction III). This broad peak was not detected when fraction II from IL 1403 was chromatographed on the Mono S column (Fig. $1 b$ ), consistent with the fact that IL 1403 lacks the immunity gene. The $A_{280}$ peak was detected when fraction II from LMG 2130 was chromatographed on the Mono S column, but not when fraction II from LMG 2131 was chromatographed (data not shown), again consistent with the fact that LMG 2130 contains the immunity gene, whereas LMG 2131 does not. The putative immunity protein eluted from the Mono $\mathrm{S}$ column as a broad peak 


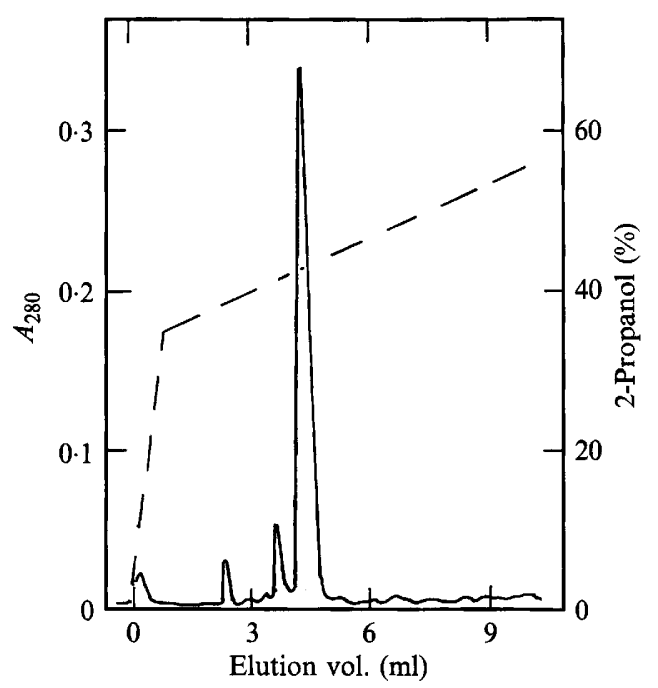

Fig. 2. Reverse-phase chromatography of fraction III prepared from strain IL 1403(pON7). The amount applied on the column represents that obtained from 2 litres of culture. The immunity protein was eluted from the column by increasing the amount of 2-propanol in $\mathrm{H}_{2} \mathrm{O}$ containing $0 \cdot 1 \%$ trifluoroacetic acid. -,$- A_{280}$; ----, 2-propanol.

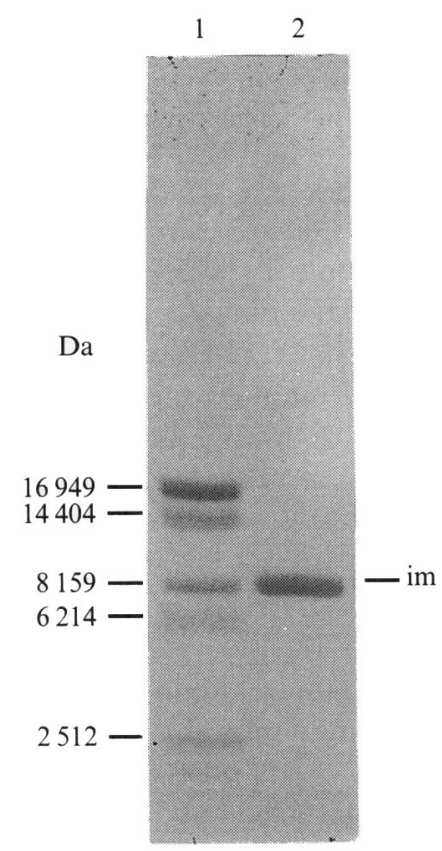

Fig. 3. SDS-PAGE analysis of the immunity protein in fraction IV obtained from strain IL 1403(pON7). Lane 1, peptide molecular mass standards (Pharmacia-LKB); lane 2, the immunity protein (im). SDSPAGE was carried out using PhastGel high-density, PhastGel-SDS buffer strips, and the PhastSystem (Pharmacia-LKB) according to the manufacturer's recommendations.

with a characteristic tailing (Fig. 1a). In addition to the salt concentration at which it eluted from the Mono $\mathrm{S}$ column, the putative immunity protein could, consequently, be identified by the characteristic shape of this broad peak.
Table 1. Purification scheme for the lactococcin A immunity protein

\begin{tabular}{|c|c|c|c|}
\hline $\begin{array}{l}\text { Purification } \\
\text { stage }\end{array}$ & $\begin{array}{l}\text { Volume } \\
\text { (ml) }\end{array}$ & Total $A_{280}{ }^{*}$ & Total $A_{254}{ }^{*}$ \\
\hline Cell culture & 2000 & & \\
\hline $\begin{array}{l}\text { Cell extract } \\
\text { (fraction I) }\end{array}$ & 20 & 200 & 900 \\
\hline $\begin{array}{l}\text { Binding to S-Sepharose } \\
\text { (fraction II) }\end{array}$ & 7 & $2 \cdot 1$ & $1 \cdot 7$ \\
\hline $\begin{array}{l}\text { Chromatography on } \\
\text { Mono } S \text { column (fraction III) }\end{array}$ & 4 & $0 \cdot 16$ & 0.08 \\
\hline $\begin{array}{l}\text { Chromatography on reverse- } \\
\text { phase column (fraction IV) }\end{array}$ & 1 & $0 \cdot 12$ & 0.05 \\
\hline
\end{tabular}

* Total $A_{280}$ and $A_{254}$ is the absorbance at the indicated wavelength multiplied by the volume in $\mathrm{ml}$.

Reverse-phase chromatography of fraction III from the Mono S column revealed only one major $A_{280}$ peak eluting at about $43 \%$ 2-propanol (fraction IV) (Fig. 2), and this peak was due to the putative immunity protein as judged by SDS-PAGE analysis (Fig. 3). The putative immunity protein was, consequently, already the dominant protein in fraction III obtained after chromatography on the Mono S column, consistent with the fact that it was the only major protein in fraction III detected by SDS-PAGE (data not shown). The $A_{280}$ profile obtained in the last reverse-phase chromatography purification step (Fig. 2) and analysis of the protein(s) eluting from the reverse-phase column (fraction IV) by SDS-PAGE (Fig. 3), indicated that the putative immunity protein was at this stage pure. Amino acid sequence analysis of fraction IV confirmed the purity, and showed that the purified protein was in fact the lactococcin A immunity protein (see below).

The purification protocol is summarized in Table 1 . The total $A_{280}$ was 200 in fraction I, and this was reduced about $10^{3}$-fold in fraction IV, where the total $A_{280}$ was 0.12 (Table 1). There was little decrease in the total $A_{280}$ going from fraction III to IV (Table 1), consistent with the observation that the immunity protein was already the dominant protein in fraction III, after chromatography on the Mono S column. Overall, this procedure for purification of the lactococcin A immunity protein is simple and rapid; and it is likely that immunity proteins for other bacteriocins may be purified by a basically similar procedure if they have a molecular mass and isoelectric point similar to those of the lactococcin A immunity protein.

\section{Characteristics of the lactococcin A immunity protein}

The sequence of the first 17 amino acid residues at the $\mathrm{N}$-terminus of the immunity protein was determined to be Met-Lys-Lys-Lys-Gln-Ile-Glu-Phe-Glu-Asn-Glu- 
Table 2. Amino acid composition of the immunity protein

\begin{tabular}{lccc}
\hline \hline $\begin{array}{l}\text { Amino } \\
\text { acid }\end{array}$ & nmol & $\begin{array}{c}\text { Calculated } \\
\text { residues per } \\
\text { molecule }\end{array}$ & $\begin{array}{c}\text { Predicted } \\
\text { residues per } \\
\text { molecule }\end{array}$ \\
\hline Ala & $6 \cdot 6$ & 8 & 8 \\
Arg & $4 \cdot 1$ & 5 & 5 \\
Asp/Asn & $9 \cdot 9$ & 12 & 12 \\
Glu/Gln & $10 \cdot 0$ & 12 & 11 \\
Gly & $4 \cdot 0$ & 5 & 4 \\
His & $0 \cdot 7$ & 1 & 1 \\
Ile§ & $5 \cdot 9$ & 7 & 8 \\
Leu & $13 \cdot 2$ & 16 & 16 \\
Lys & $8 \cdot 1$ & 10 & 10 \\
Met & $2 \cdot 2$ & 3 & 3 \\
Phe & $2 \cdot 4$ & 3 & 2 \\
Pro & $2 \cdot 0$ & 2 & 8 \\
Ser & $6 \cdot 2$ & $7-8$ & 4 \\
Thr & $3 \cdot 1$ & 4 & 1 \\
Trp & ND & - & 0 \\
Tyr & $1 \cdot 8$ & 2 & 98 \\
Val & $0 \cdot 3$ & 0 & \\
Total no. of & & $97-98$ & \\
amino acid residues & & & \\
\hline \hline
\end{tabular}

ND, Not determined.

* nmol measured of the indicated amino acid residue: gives the relative amount of the indicated amino acid residue in one immunity protein molecule.

†Calculated from the relative amount of the indicated amino acid residue, assuming the presence of 97 amino acid (not including Trp, which was not measured in the composition analysis) residues per immunity protein molecule.

$\ddagger$ The number of residues per immunity protein molecule as predicted by the immunity protein gene sequence (Holo et al., 1991; van Belkum et al., 1991a), assuming that the immunity protein is not posttranslationally cleaved.

$\S$ The immunity protein contains an Ile-Ile bond which may require more than the $24 \mathrm{~h}$ hydrolysis time used in order to obtain complete hydrolysis.

Leu-Arg-Ser-Met-Leu-Ala-. This sequence is identical to that predicted by the immunity gene sequence (Holo et al., 1991; van Belkum et al., 1991a), proving that the isolated protein was in fact the immunity protein. Moreover, the $\mathrm{N}$-terminal amino acid sequence shows that the immunity protein is not post-translationally processed by cleavage at the $\mathrm{N}$-terminal end. This is in contrast to the bacteriocin itself, in which the 21-aminoacid-residue $\mathrm{N}$-terminal region is missing in the extracellular and active lactococcin A molecule (Holo et al., 1991).

The C-terminal sequence was determined to be ?-TrpGly-?-Leu-Phe after cyanogen bromide cleavage of the immunity protein at the methionine residue at position 92. This sequence is also consistent with that predicted by the immunity gene sequence (Holo et al., 1991; van Belkum et al., 1991a), showing that the protein is not post-translationally processed by cleavage at the Cterminal end. The amino acid composition of the immunity protein was also largely as one would expect if the immunity protein is not post-translationally cleaved (Table 2). The major differences in the determined composition and that expected from the gene sequence are that the composition obtained suggests the presence of 12, 5 and 7 residues, respectively, of glutamine/glutamic acid, glycine and isoleucine, whereas the gene sequence predicts, respectively, 11,4 and 8 residues (Table 2). The discrepancy seen for isoleucine is probably due to the Ile-Ile peptide bond at position 48-49 which may not have been completely hydrolysed.

Since the immunity protein was not post-translationally cleaved, its absorption coefficient, isoelectric point and molecular mass may be determined from the predicted amino acid sequence. The absorption coefficient at $280 \mathrm{~nm}$ was calculated to be $8.2 \times 10^{3} \mathrm{M}^{-1} \mathrm{~cm}^{-1}$ and the isoelectric point $10 \cdot 2$. The molecular mass was calculated to be $11163 \mathrm{Da}$, somewhat more than the $8000-9000 \mathrm{Da}$ suggested by SDS-PAGE. SDS-PAGE, however, may not always give accurate molecular mass estimates for peptides with a molecular mass less than $20000 \mathrm{Da}$. From the absorption coefficient, molecular mass and the amount purified from 2 litres of culture (Table 1), one may estimate (to an order of magnitude) that $10^{5}$ immunity protein molecules are present per cell, assuming that the recovery of the protein upon purification is between 20 and $2 \%$. Thus the immunity protein appears to be a major cell protein component.

Exposing the lactococcin-A-sensitive strain IL 1403 to an excess of purified or partially purified immunity protein before exposure to lactococcin A did not affect the lactococcin A-induced killing of the cells, and neither did exposing lactococcin A to an excess of the immunity protein prior to addition of the cells (data not shown). This suggests that the immunity protein does not simply protect cells from lactococcin A by directly binding to and thereby inactivating the bacteriocin, nor by directly binding to externally exposed domains on the cell surface, such as a putative bacteriocin receptor. Exposing IL 1403(pON7) cells, which contain the immunity gene and are thus resistant to lactococcin $\mathrm{A}$, to antiserum against the immune protein did not sensitize the cells to lactococcin $\mathrm{A}$, even when the cells had been pretreated with lysozyme (data not shown). This again suggests that, although the immunity protein is associated with the cell membrane (see below) it does not act outside the cell.

\section{Association of the immunity protein with the cell membrane}

Immunoblot analysis of membrane-associated proteins from the immune strain LMG 2130 indicated that the immunity protein is associated with the cell membrane (Fig. 4). Almost $50 \%$ of the immunity protein detected 


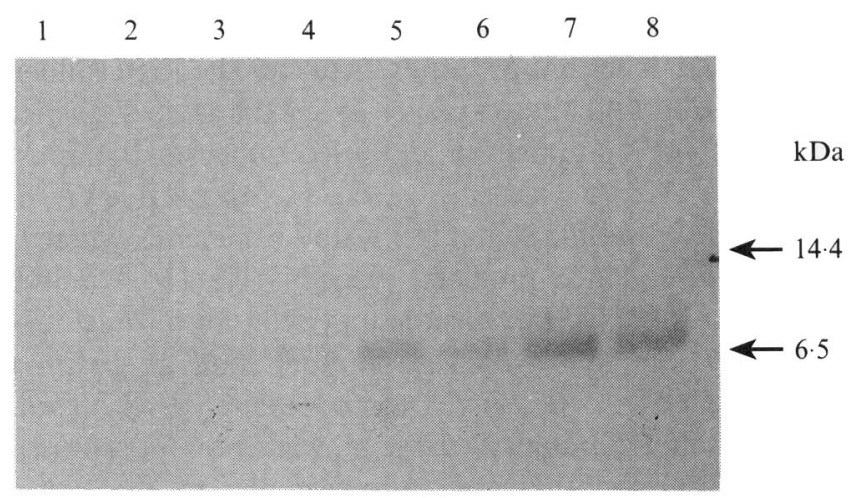

Fig. 4. Immunoblot analysis of cytosol-associated and membranevesicle-associated proteins of strains LMG 2131 (lanes 1 and 2) and LMG 2130 (lanes 3-8) using antiserum raised against the purified immunity protein. The final volume of the membrane and cytosol fractions prepared from $200 \mathrm{ml}$ cell cultures was $3 \mathrm{ml}$, and the following volumes of these fractions were loaded on the gel: $25 \mu 1$ on lanes 1, 2, 7 and $8 ; 8 \mu \mathrm{l}$ on lanes 5 and $6 ; 2 \cdot 5 \mu \mathrm{l}$ on lanes 3 and 4 . Cytosol fractions were loaded on lanes $1,3,5$ and 7 , and membrane fractions on lanes 2 , 4, 6 and 8. Positions of molecular mass standard proteins are shown on the right.

in cells was associated with the membrane fraction (Fig. 4), and this fraction was relatively free of cytosolic enzymes. There was 140 times more activity of lactate dehydrogenase, a cytosolic enzyme, in the cytosolic fraction (70000 units $\mathrm{ml}^{-1}$ ) than in the membrane fraction $\left(500\right.$ units $\left.\mathrm{ml}^{-1}\right)$. Adding Triton X-100 [0.4 and 1\% (v/v)] to disrupt membrane vesicles did not affect the amount of lactate dehydrogenase measured, indicating that the relatively low amount of this enzyme in the membrane fraction was not simply due to entrapment of the enzyme within membrane vesicles. The same distribution of the immunity protein between the membrane and cytosolic fractions was also found in the immune strain IL 1430(pON7) (data not shown).

The immunity protein was also found in the cytosolic fraction (Fig. 4). Its presence in this fraction may have been due to: (i) the existence of both a membraneassociated and a cytosolic pool of the immunity protein, (ii) the presence of small membrane vesicles in the cytosolic fraction, and/or (iii) the release of membrane-associated proteins during fractionation of the membrane vesicles - the immunity protein is probably a peripheral membrane protein (see below) and might, consequently, be loosely associated with the membrane. The immunity protein band detected in Fig. 4 migrated identically with purified immunity protein (data not shown). No immunity protein was detected in the immune-negative strains, LMG 2131 (Fig. 4, lanes 1 and 2) and IL 1403 (data not shown), indicating that the antiserum was specific.

Judging from its amino acid sequence, the immunity protein is relatively hydrophilic and thus it is not a typical integral membrane protein. It is more likely to be a peripheral membrane protein, perhaps associated with an integral membrane protein on the inside of the cell through electrostatic and hydrogen bonding interactions. By interacting with an integral membrane protein, the immunity protein might possibly prevent binding of lactococcin $\mathrm{A}$ to cells and/or lactococcin-A-induced membrane pore formation. The evidence that the immunity protein is associated with the cell membrane is consistent with earlier studies which showed that lactococcin A inhibits leucine uptake in membrane vesicles of sensitive strains, but not in membrane vesicles of resistant strains carrying the immunity gene (van Belkum et al., 1991b).

The purification of the immunity protein and the availability of antiserum raised against the purified protein will permit further characterization of how immunity functions: for instance by studying how the incorporation of the immunity protein into membrane vesicles affects leucine uptake upon exposing the vesicles to lactococcin A.

H. Holo was supported by grants from the Norwegian Dairies Association.

\section{References}

van Belkum, M. J., Hayema, B. J., Jeeninga, R. E., KoK, J. \& VENEMA, G. (1991 $a$ ). Organization and nucleotide sequences of two lactococcal bacteriocin operons. Applied and Environmental Microbiology 57, 492-498.

van Belkum, M. J., Kok, J., Venema, G., Holo, H., Nes, I. F., KONINGS, W. N. \& ABEE, T. (1991 b). The bacteriocin lactococcin A specifically increases the permeability of lactococcal cytoplasmic membranes in a voltage-independent, protein mediated manner. Journal of Bacteriology 173, 7934-7941.

BRADFORD, M. M. (1976). A rapid and sensitive method for the quantitation of microgram quantities of protein utilizing the principle of protein-dye binding. Analytical Biochemistry 72, 248-254.

Buchman, G. W., Banerjee, S. \& Hansen, J. N. (1988). Structure, expression, and evolution of a gene encoding the precursor of nisin, a small protein antibiotic. Journal of Biological Chemistry 263, 16260-16266.

Dodd, H. M., Horn, N. \& Gasson, M. J. (1990). Analysis of the genetic determinant for production of the peptide antibiotic nisin. Journal of General Microbiology 136, 555-566.

Gross, E. \& MoRell, J. (1971). The structure of nisin. Journal of the American Chemical Society 93, 4634-4635.

Hastings, J. W., Sailer, M., Johnson, K., Roy, K. L., Vederas, J. C. \& STILES, M. (1991). Characterization of leucocin A-UAL 187 and cloning of the bacteriocin gene from Leuconostoc gelidum. Journal of Bacteriology 173, 7491-7500.

Henderson, J. T., Chopko, A. L. \& van WassenaAR, P. D. (1992). Purification and primary structure of pediocin PA-1 produced by Pediococcus acidilactici PAC-1.0. Archives of Biochemistry and Biophysics 295, 5-12.

Holo, H., NilsSEN, Ø. \& NeS, I. F. (1991). Lactococcin A, a new bacteriocin from Lactococcus lactis subsp. cremoris: isolation and characterization of the protein and its gene. Journal of Bacteriology 173, 3879-3887.

Houng, H.-S., Lynn, A. R. \& Rosen, B. P. (1986). ATP-driven calcium transport in membrane vesicles of Streptococcus sanguis. Journal of Bacteriology 168, 1040-1044.

HURST, A. (1981). Nisin. Advances in Applied Microbiology 27, 85-123. 
Kaletta, C. \& Entian, K.-D. (1989). Nisin, a peptide antibiotic: cloning and sequencing of the nisA gene and posttranslational processing of its peptide product. Journal of Bacteriology 171, $1597-1601$.

KonisKy, J. (1982). Colicins and other bacteriocins with established modes of action. Annual Review of Microbiology 36, 125-144.

LAEMMLI, U. K. (1970). Cleavage of structural proteins during the assembly of the head of bacteriophage T4. Nature, London 227, 680-685.

Mørtvedt, C. I., Nissen-Meyer, J. \& Nes, I. F. (1991). Purification and amino acid sequence of lactocin $\mathrm{S}$, a bacteriocin produced by Lactobacillus sake L45. Applied and Environmental Microbiology 57, 1829-1834.

Muriana, P. M. \& KlaenhammeR, T. R. (1991 a). Cloning, phenotypic expression, and DNA sequence of the gene for lactacin $F$, an antimicrobial peptide produced by Lactobacillus spp. Journal of Bacteriology 173, 1779-1788.

Muriana, P. M. \& Klaenhammer, T. R. (1991 b). Purification and partial characterization of lactacin $\mathrm{F}$, a bacteriocin produced by Lactobacillus acidophilus 11088. Applied and Environmental Microbiology 57, 114-121.

Nieto Lozano, J. C., Nissen-Meyer, J., Sletten, K., Pelaz, C. \& Nes, I. F. (1992). Purification and amino acid sequence of a bacteriocin produced by Pediococcus acidilactici. Journal of General Microbiology 138, 1985-1990.

Nissen-Meyer, J., Holo, H., Håvarstein, L. S., Sletten, K. \& Nes, I. F. (1992). A novel lactococcal bacteriocin whose activity depends on the complementary action of two peptides. Journal of Bacteriology 174, 5686-5692.

Piard, J.-C., Muriana, P. M., Desmazeaud, M. J. \& Klaenhammer, T. R. (1992). Purification and partial characterization of lacticin 481, a lanthionine-containing bacteriocin produced by Lactococcus lactis subsp. CNRZ 481. Applied and Environmental Microbiology 58, 279-284.

SAHL, H.-G., KoRdel, M. \& BeNZ, R. (1987). Voltage-dependent depolarization of bacterial membranes and artificial lipid bilayers by the peptide antibiotic nisin. Archives of Microbiology 149, 120-124.

Stoffels, G., Nissen-Meyer, J., Gudmundsdottir, A., Sletten, K., Holo, H. \& NEs, I. F. (1992). Purification and characterization of a new bacteriocin isolated from a Carnobacterium sp. Applied and Environmental Microbiology 58, 1417-1422.

TAGG, J. R., DaJANI, A. S. \& WANNAMAKeR, L. W. (1976). Bacteriocins of Gram-positive bacteria. Bacteriological Reviews 40, 722-756.

TichaczeK, P. S., Nissen-Meyer, J., Nes, I. F., Vogel, R. F. \& HAMMES, W. P. (1992). Characterization of the bacteriocins curvacin A and sakacin P produced by Lactobacillus curvatus LTH1174 and L. sake LTH673. Systematic and Applied Microbiology 15, 460-468. 